\title{
The socio-labor implications in vocational training and its relationship with curriculum design and training
}

\section{Las implicaciones sociolaborales en la formación profesional y su relación con el diseño y la formación curricular}

\author{
YAÑEZ-FLORES, Sara Margarita†*, HERNÁNDEZ-CUETO, Jaquelina Lizet, SALINAS-AGUIRRE, \\ María del Consuelo and DELGADO-TALANCÓN, Daniela
}

Universidad Autónoma de Coahuila, Faculty of Science, Education and Humanities, Saltillo Campus.

ID $1^{\text {st }}$ Author: Sara Margarita, Yañez-Flores / ORC ID: 0000-0002-4750-4244, Researcher ID Thomson: S-9231-2018, CVU CONACYT ID: 352125

ID $1^{\text {st }}$ Co-author: Jaquelina Lizet, Hernández-Cueto / ORC ID: 0000-0002-3728-7434, Researcher ID Thomson: S-85882018, CVU CONACYT ID: 322702

ID $2^{\text {nd }}$ Co-author: María del Consuelo, Salinas-Aguirre / ORC ID: 0000-0002-6542-1813, Researcher ID Thomson: S9244-2018, CVU CONACYT ID: 615335

ID $^{3 r d}$ Co-author: Daniela, Delgado-Talancón

DOI: $10.35429 / J S E M .2021 .22 .8 .24 .31$

Received January 25, 2021; Accepted June 30, 2021

\begin{abstract}
University professional training is the sum of individual and group efforts that are intertwined as students and teachers advance, semester or annually. It has its precedent in curricular designs and may or may not be spiced up with job training. The objective is to analyze the relationships of the elements of professional training, curriculum design and training from the university perspective. The present study is quantitative, cross-sectional and with a sample by availability. 18 variables that make up the axes of Vocational Training (8), Training (4) and Curricular Design (4) are analyzed, the results of which have been treated with Pearson's Product Moment Correlation analysis; the scale used is decimal ratio. The participants were 65 teachers and 138 students from different Academic Units. It is stated that the themes that allude to the social rights, rights, and obligations of the workers, the Afores, the educational-labor reforms should be considered as cross-cutting themes in any university career due to their socio-educational-labor implications.
\end{abstract}

Vocational training, Curriculum design, Training

\begin{abstract}
Resumen
La formación profesional universitaria, es la suma de esfuerzos individuales y grupales que se van entrelazando conforme los estudiantes y docentes avanzan, semestral o anualmente. Tiene su precedente en los diseños curriculares y puede ser o no aderezado con la capacitación laboral. El objetivo es analizar las relaciones de los elementos de la formación profesional, el diseño curricular y capacitación desde la perspectiva universitaria. El presente estudio es de corte cuantitativo, transversal y con una muestra por disponibilidad. Se analizan 18 variables que integran los ejes de Formación profesional (8), Capacitación (5) y Diseño Curricular (5) cuyos resultados han sido tratados con el análisis de Correlación Producto Momento de Pearson; la escala utilizada es decimal de razón. Los participantes fueron 65 docentes y 138 estudiantes de diferentes Unidades Académicas. Se afirma que las temáticas que aluden a los derechos sociales, derechos y obligaciones de los trabajadores, las afores, las reformas educativo-laborales deben de considerarse como temáticas transversales en cualquier carrera universitaria por sus implicaciones socioeducativas-laborales.
\end{abstract}

Professional training, Curriculum design, Training

Citation: YAÑEZ-FLORES, Sara Margarita, HERNÁNDEZ-CUETO, Jaquelina Lizet, SALINAS-AGUIRRE, María del Consuelo and DELGADO-TALANCÓN, Daniela. The socio-labor implications in vocational training and its relationship with curriculum design and training. Journal of Systems and Educational Management. 2021. 8-22:24-31.

*Correspondence to Author (Email: sarayanez@uadec.edu.mx)

$\dagger$ Researcher contributing as first Author. 


\section{Introduction}

In University vocational training presents serious setbacks with its environment since the requirements for graduates to join and adapt to the different social, labor, and scientifictechnological processes is not presented in a balanced way due to socioeconomic inequalities, the gap of scientific and technological advances between the university and the productive sector and, among others, to the demands that employers impose on applicants.

The debate is still ongoing around the characteristics that the processes of university education must have and gather to achieve and satisfy the social and labour demands; it is not an easy task and university training processes continue to be pointed out as responsible for the slowness of the entry of their graduates into the labor sector.

The article the socio-occupational implications of vocational training and its relationship with curriculum design and training is broken down into different sections which allow interaction with what has been presented; in section 2, the relationship between vocational training, curriculum design and training is addressed from the point of view of authors, institutions, and legislation in force. Regarding the Methodology, it is found in Section 3 that alludes to the type of research, the sample, and the integrating variables of the three axes analyzed; it also indicates the types of statistical treatments with which the data were analyzed. In Section 4, the demographic, and socioeducational results of the sample of the 203 university students who participated voluntarily in this study are presented, in addition to the correlational analysis of the 18 integrating variables of the three axes: Professional Training, Curricular Design and Training. Finally, section 5 presents the significant conclusions of the study; it also indicates whether the objectives were achieved, and the hypothesis accepted.

\subsection{Formal object}

Invariably, when vocational training is approached, the field of education and the labour market are related to the challenge that the incorporation of their future graduates into the productive sector means for universities.
On the Cuban university the concept of dimension is incorporated, "To characterize the way in which a process can be studied, analyzed from different positions, approaches in correspondence with a particular purpose in each case" (Horruitine, 2009 p. 15) According to this proposal, there are three dimensions:

Instructive dimension, related to the idea that to prepare a professional, it is necessary to instruct him. This implies providing them with the necessary knowledge and skills of their profession, prepared to use them when performing as such in a certain job. Development dimension, where professional skills are divided to ensure their successful work performance and the educational dimension, that young person who is today in university classrooms lives in society, is a social being and the university also has the obligation to train him to live in that society (op.cit p. 16)

From the proposed study, the three dimensions explained by Horruitine (2009) can be adopted to any professional training process since the three are intertwined allowing to outline the professional training of active students and future graduates.

This study does not delve into the complex relationships between university and the labour market, but rather elucidates the underlying relationships between the elements of vocational training, curriculum design and training from the perspective of teachers and university students.

\subsubsection{Objectives}

\section{a. General objective}

Explain the relationships of the elements of vocational training, curriculum design and training.

\section{b. Specific objectives}

Describe the demographic and socio-educational profiles of the participants.

Analyze the relationships of the elements of professional training, curriculum design and training from the university perspective. 


\subsubsection{Hypothesis}

It assumes that the elements of Vocational Training, Curriculum Design and Training present significant relationships given their characteristics and importance within university vocational training.

\section{Relationships between vocational training, curriculum design and training}

\subsection{Vocational training and curriculum design: impact on the productive sector}

University vocational training is linked to three dimensions that underpin it in the socioeducational, labour, scientific-technological and cultural fields; from the instructive, development and educational dimension, vocational training provides the knowledge, skills, abilities, and values that are necessary for insertion into the productive sector, as entrepreneurs and job creators, but also as employees with living wages. (Horruitine, 2009).

For his part, Llerena (2015) indicates that the integrality of professional training is based on the continuous review and improvement of the curricula and programs of study, which contemplate the inter and multidisciplinarity of the subjects; likewise, "theeffective application of pedagogical and didactic methods that favor an effective insertion of the graduates in their professional practice". (p.2) For Inciarte (2009) the integral formation alludes to the fact that:

... university education requires expanding its range of options by organically articulating transversal axes with the following planes: the understanding of the languages of diverse disciplines, the critical use of technology, the mastery of symbolic languages, the development of sensitivity to the humanities and the arts, and the cultivation of the body through physical activities. (p. 42)

What underlies in "the understanding of the languages of diverse disciplines" (op. cit), is adaptable to the inclusion of topics that address the laws that protect work and the worker, as well as to the reforms that ineducational-labor matters that are being implemented in Mexico, because it provides the student with critical and reflective views of their future in the work environment.
Some thematic careers in the field of legislation and educational-labor reforms are topics "obliged" to know and analyze by students but it is necessary that they are transversal themes in any professional profile due to the socio-occupational implications of them.

It is therefore pertinent that issues of social rights, the rights and obligations of workers, legal forms of hiring, as well as what refers to informality, employment, underemployment... among other issues of equal importance, are addressed and analyzed in the different university careers; since it is not unknown that students even before graduating already work to help in their sustenance and, in many of the occasions, their hirings do not cover the minimum essential required by law.

As Inciarte (2009) comments, the new models require that curricular articulation be based on cross-cutting themes such as the promotion of values, student mobility, flexible programs, and the re-dimensioning of "disciplines around the fields of socially sensitive problems". (p. 43)

In this context, Sánchez (2014) points out that it is indispensable "... assume a critical and flexible curricular stance, committed to the network composed of academic knowledge and everyday knowledge that strengthens the sense of solidarity, dignity, responsibility and sensitivity in the human being. (p.71) In addition, the trans-disciplinarity of the curriculum is proposed from the decentralization of ideas:

... assume it from a rhizomatic position that admits gateways and multiple strategies to interconnect, interwoose and transversalize both the organization and the programs, the knowledge, the management, where the training spaces become meeting points for the emergence of a citizenry that sprouts the recognition of diverse sources of reality. (op.cit., p. 71) 
Vocational training is not only about the memorization and accumulation of information but rather about that information being meaningful that allows students to develop skills, abilities, values, attitudes to face and "... adapt to a changing, uncertain and complex world, which demands from people in training a process of transformation, necessary to live in today's society characterized by its permanent state of change at a global level..." ((Hargreaves, 2003). (Ap. Altuna, et.al., 2021, p. 198)

However, the OECD (2019) indicates that employers maintain the position that university graduates have deficiencies in required competencies, such as specific knowledge and transversal competences; likewise, the CIDAC (2014) reported that graduates lacked the skills related to written and oral communication in both Spanish and English and limited skills in synthesizing information, logical thinking, and little sense of responsibility. (pp.23-25)

\section{But how Inciarte (2009) points out:}

It goes without saying that higher education cannot be subordinated to the regularities imposed by market dynamics; on the contrary, it must continue to contribute to the definition of sovereignty and to the formation of being, identity, history, and the future, in a permanent definition of pedagogical and social utopias. (p.43)

\subsection{Vocational training and training: their complementarity}

What corresponds to training, employers insist on pointing out the deficiencies that graduates present to improve their performance, but the OECD (2019), points out that "Mexican companies do not have a training culture to increase or update the skills of their employees, and the incentives for them to do so are limited". (p. 151)

The culture of training is regulated in the Political Constitution of the United Mexican States (CPEUM, 2021), in article 123, section A Fraction XIII clearly states that it is the obligation of companies to train workers that would help to improve their professional skills.
The Federal Labor Law (LFT, 2021) identifies the different provisions in labor matters; specifically in Chapter III Bis on the Productivity, Training and Training of Workers (Added Chapter DOF 28-04-1978. Reformed denomination DOF 30-11-2012) are the different articles and fractions that indicate the mandatory training or training.

The purpose of the training is to improve the quality of life of the worker; increase productivity, prevent occupational risks; improve the skills and knowledge of workers and prepare them for new positions or fill vacancies. All this framed and endorsed by the Secretariat of Labor and Social Security (STyPS) in its forms, places, and delivery of training, as well as in the Law Organic of the Federal Public Administration (LOAPF,2021) and in the Internal Regulations of the Secretariat of Labor and Social Security (RISTyPS, DOF 23-08-2019), are addressed, regulated, and regulated labor training.

The OECD (2019) reveals that in Mexico some reforms were undertaken in terms of fiscal policy, deregulation of telecommunications which were successful, but not what alludes to:

... reforms in labor matters and the fight against informality, quality of education, anticorruption and transparency, judicial processes and fiscal federalism have been less successful. Reforms in the areas of unemployment insurance, pensions and social benefits, the health system, urban planning, and agricultural transformation have made less progress (p.73).

The relationships between professional training, curriculum design and training are evident from the approach and proposals of the literature consulted; their relationships are complex due to the socio-educational-labor implications given the university contextual conditions where they develop.

\section{Methodology}

\subsection{Type of research}

The research the socio-occupational implications in vocational training and its relationship with curricular design and training, is quantitative, correlative-explanatory and transversal (November-March 2021). 
The results are explored and analyzed from the teacher-student perspective since it is considered that this perspective better evidences the perceptions of professional training, curriculum design and training.

\subsection{Scope of study and Sample}

The study was carried out at the Autonomous University of Coahuila with the participation of students and teachers from different Academic Units (psychology, chemical sciences, nursing...). An exprofessal instrument was designed in Microsoft Forms $@$ and sent via mass mail and relied on social networks for dissemination. The sample was by availability and whoever voluntarily wanted to answer the instrument; the characteristics for sending and possible responses alluded to undergraduate, graduate, and full-time faculty (PTC) students, part-time and/or PTC faculty and civil servant.

\subsection{Variables}

Three axes Professional Training, Curriculum Design and Training are analyzed, each one made up of 10 variables; However, for the present study, only the variables with the greatest significance were chosen for the case of the Curricular design and Training axes in relation to the Vocational Training variables. The scale used for the correlation statistic was a decimal ratio (0-10).

In addition to the simple variables that make up each axis, demographic and socioeducational variables were used to contextualize the questions-answers described above.

\section{Results}

\subsection{Demographic and socio-educational characteristics}

Of the 203 respondents ( $n=65$ teachers and $n=138$ students) the majority are women (Table 1). The ages of students are between 17 and 25 years and that of teachers between 38 and 58 years.

Students were identified as ages from 35 to 58 , representing graduate students; in the case of teachers, ages were identified from 23 to 29 years and even from ages 60 to 71 years, some of them are part-time teachers with seniority of 30 years.

\begin{tabular}{|l|c|l|l|c|l|}
\hline \multicolumn{4}{|c}{ Teachers } & \multicolumn{4}{c|}{ Students } \\
\hline Variable & fr & $\%$ & Variable & fr & $\%$ \\
\hline Women & 35 & 53.85 & woman & 97 & 70.29 \\
\hline Men & 30 & 46.15 & man & 41 & 29.71 \\
\hline
\end{tabular}

Table 1 Sample description by sex

The majority are undergraduate students and only $7.88 \%$ study postgraduate studies; this refers to the 65 teachers, $8.87 \%$ are part-time and three serve two functions. (Table 2).

\begin{tabular}{|l|r|r|}
\hline \multicolumn{1}{|c}{ Variable } & \multicolumn{1}{c}{ fr } & \multicolumn{1}{c|}{$\%$} \\
\hline Undergraduate student & 122 & 60.10 \\
\hline PTC & 44 & 21.67 \\
\hline Part-time teacher & 18 & 8.87 \\
\hline Graduate student & 16 & 7.88 \\
\hline PTC and official & 3 & 1.48 \\
\hline
\end{tabular}

Table 2 Sample description by occupation

From the analysis of the socioeducational data, it was identified that the teachers come from 24 Academic Units and the students from 32; when the database was reviewed, a balance was observed between participating teachers and students.

\subsection{Axes Vocational training, Curriculum design and Training: Correlational Analysis}

In addition to the demographic and socioeducational description of the participating population, a pearson product moment correlational analysis was performed to know the relationships that underlie the axes of Vocational Training, Training and Curricular Design using a correlation coefficient of $r^{2}=0.40$ with a probable level of error of 0.05 .

The readings of Tables 3; 4; 5 and 6 , are readn from the integrating variables of Vocational Training [top of the same] and the relationships that stand out from the variables that make up the axis Curricular Design and Training [first left column]. 


\begin{tabular}{|l|r|r|}
\hline \multicolumn{1}{|c|}{ Variables } & \multicolumn{1}{c|}{$\begin{array}{c}\text { Socio- } \\
\text { partner } \\
\text { involvement } \\
\text { Labour }\end{array}$} & $\begin{array}{c}\text { Educational- } \\
\text { labor } \\
\text { reforms }\end{array}$ \\
\hline Traits of the profile exit & 0.14 & 0.24 \\
\hline Professional skills & 0.14 & 0.21 \\
\hline Educational reforms & 0.30 & $\mathbf{0 . 4 4}$ \\
\hline Policies public & 0.31 & $\mathbf{0 . 4 2}$ \\
\hline $\begin{array}{l}\text { Employment } \\
\text { Sure }\end{array}$ & 0.31 & $\mathbf{0 . 4 3}$ \\
\hline Professional preparation & $\mathbf{0 . 5 0}$ & $\mathbf{0 . 4 9}$ \\
\hline Job opportunities & 0.31 & 0.39 \\
\hline $\begin{array}{l}\text { Success of the } \\
\text { worker }\end{array}$ & 0.33 & $\mathbf{0 . 4 2}$ \\
\hline
\end{tabular}

Table 3 Correlational analysis of Vocational training, Curriculum design and Training

About the socio-occupational implication of issues related to employment (unemployment, informality, underemployment...) the respondents associate it with the training that replaces the university professional preparation to work (Table 3 ).

Both teachers and students agree in stating (Table 3) that the educational-labor reforms as implications in the socio-labor reality are linked to the elements of the Curricular Design that refer to the reforms and the educational public policies and shows that the Training a intervenes as an aid to achieve a secure employment with good remuneration while replacing the university professional preparation to work and the success of the worker.

The topics that are addressed in the Vocational Training of the Academic Units such as training as an aid to have a decent job, the incidence of Professional Training in the sociolabor reality, the characteristics of decent work (human dignity, social security) find affinity with professional skills for the labor marketl, educational reforms and in public educational policies and are related to issues related to Training as a help to achieve a secure job with good remuneration, which improves job opportunities in the labor market and the success of the worker (Table 4).

\begin{tabular}{|l|r|r|r|}
\hline \multicolumn{1}{|c}{ Variables } & $\begin{array}{c}\text { Decent } \\
\text { employment } \\
\text { training }\end{array}$ & $\begin{array}{c}\text { Incidence } \\
\text { of } \\
\text { vocational } \\
\text { training }\end{array}$ & $\begin{array}{c}\text { Work } \\
\text { worthy }\end{array}$ \\
\hline Traits of the profile exit & 0.36 & 0.39 & 0.39 \\
\hline Professional skills & $\mathbf{0 . 4 4}$ & $\mathbf{0 . 4 0}$ & $\mathbf{0 . 4 1}$ \\
\hline Educational reforms & $\mathbf{0 . 4 1}$ & 0.37 & 0.31 \\
\hline Policies public & $\mathbf{0 . 4 4}$ & $\mathbf{0 . 4 6}$ & $\mathbf{0 . 4 3}$ \\
\hline Employment sure & $\mathbf{0 . 4 8}$ & $\mathbf{0 . 5 5}$ & $\mathbf{0 . 6 1}$ \\
\hline Professional preparation & 0.37 & 0.33 & 0.39 \\
\hline Job opportunities & $\mathbf{0 . 5 7}$ & $\mathbf{0 . 4 9}$ & $\mathbf{0 . 5 2}$ \\
\hline $\begin{array}{l}\text { Success of } \\
\text { the worker }\end{array}$ & $\mathbf{0 . 5 2}$ & $\mathbf{0 . 5 4}$ & $\mathbf{0 . 5 7}$ \\
\hline
\end{tabular}

Table 4 Correlational analysis of Vocational training, Curriculum design and Training

Table 5 shows that the rules and norms for effective communication and social rights (right to health, education...), are part of public educational policies and indicate that Training helps to achieve secure employment with good pay, improves job opportunities in the labor market, which results in the success of the worker.

\begin{tabular}{|l|r|r|}
\hline \multicolumn{1}{|c}{ Variables } & \multicolumn{1}{c|}{$\begin{array}{c}\text { Rules- } \\
\text { standards }\end{array}$} \\
\hline $\begin{array}{l}\text { Traits of the } \\
\text { profile exit }\end{array}$ & 0.35 & 0.33 \\
\hline Professional skills & 0.39 & 0.39 \\
\hline Educational reforms & 0.36 & 0.31 \\
\hline $\begin{array}{l}\text { Policies } \\
\text { Public }\end{array}$ & $\mathbf{0 . 4 0}$ & $\mathbf{0 . 4 1}$ \\
\hline $\begin{array}{l}\text { Employment } \\
\text { sure }\end{array}$ & $\mathbf{0 . 4 7}$ & $\mathbf{0 . 5 0}$ \\
\hline Professional preparation & 0.32 & 0.39 \\
\hline Job opportunities & $\mathbf{0 . 5 1}$ & $\mathbf{0 . 4 8}$ \\
\hline $\begin{array}{l}\text { Success of } \\
\text { the worker }\end{array}$ & $\mathbf{0 . 5 3}$ & $\mathbf{0 . 5 0}$ \\
\hline
\end{tabular}

Table 5 Correlational analysis of Vocational training, Curriculum design and Training

In Table 6, it is identified that for the participants what refers to the before and now of saving, the afores, pensions in the social educational reality of work only presents relation with public policies of the axis of Curricular Design. However, when vocational training addresses the issues of rights and obligations as a worker, legal conditions in terms of hiring, the before and now of savings, afores, pensions in the reality socio-educational labor, training replaces the university professional preparation to work and contributes to the success of the worker. 


\begin{tabular}{|l|r|r|r|}
\hline \multicolumn{1}{|c|}{ Variables } & \multicolumn{1}{c}{$\begin{array}{c}\text { Rights and } \\
\text { obligations }\end{array}$} & \multicolumn{1}{c|}{$\begin{array}{c}\text { Legal } \\
\text { conditions }\end{array}$} & \multicolumn{1}{c|}{$\begin{array}{c}\text { Saving } \\
\text { capacity... }\end{array}$} \\
\hline Traits of the profile exit & 0.28 & 0.21 & 0.20 \\
\hline Professional skills & 0.33 & 0.22 & 0.21 \\
\hline Educational reforms & 0.25 & 0.31 & 0.31 \\
\hline Policies public & 0.32 & 0.39 & $\mathbf{0 . 4 0}$ \\
\hline Employment sure & $\mathbf{0 . 4 8}$ & 0.37 & 0.33 \\
\hline Professional preparation & $\mathbf{0 . 4 1}$ & $\mathbf{0 . 4 6}$ & $\mathbf{0 . 4 6}$ \\
\hline Job opportunities & $\mathbf{0 . 4 6}$ & 0.34 & 0.28 \\
\hline Success of the worker & $\mathbf{0 . 4 7}$ & $\mathbf{0 . 4 0}$ & 0.33 \\
\hline
\end{tabular}

Table 6 Correlational analyses of Vocational training, Curriculum design and Training

\section{Conclusions}

The relationships that emerge from the elements of vocational training, curriculum design and training tend mostly to robust concordance between the variables of vocational training and training. And it was identified that the traits of the graduation profile (curricular design axis) do not present any significant correlation.

It is interesting to note that the relevance of training if it is clear in the university community as indicated by the Federal Labor Law (LFT,2021) which identifies the different provisions in labor matters, articles and fractions that indicate the mandatory training or training by companies for the benefit of their employees. Likewise, as indicated in the labor laws, the purpose of training is to improve the quality of life of the worker; to increase productivity, prevent occupational risks; to improve the skills and knowledge of workers and to prepare them for new positions or fill vacancies.

Teachers and students agree that the vocational training of the different university careers addresses issues related to social and labour incidences related to employment, types of recruitment, social rights, rights, and obligations and what refers to educational-labor reforms; at this point what remains to be investigated is whether these topics are transversal or are part of the curriculum design. Since it is observed that the correlations presented between vocational training and curricular design present, for the most part, values below the $\boldsymbol{r}^{2}=\mathbf{0 . 4 0}$; although it can be ventured to point out that they are transversal themes since the traits of the graduation profile (curricular design axis) with the variables of professional training and training did not find underlying relationships.
The above is seen in the relations with the rights and obligations as a worker and the legal conditions in terms of hiring and the Afores, savings, pensions... they are not topics considered in the traits of the graduation profile, professional competencies for the labor market, educational reforms and public policies, variables of the curricular design axis.

It is not only to wait for educational and labor reforms to take place, but also necessary to socialize them with students to encourage a critical and reflective attitude around it, since as indicated by the OECD (2019) "... reforms in the areas of unemployment insurance, pensions and social benefits, the health system... less progress has been made" (OECD, 2019 p.73).

According to the analyses presented, the hypothesis raised ... the elements of Professional Training, Curricular Design and Training present significant relationships given their characteristics and importance within the university professional training, it is not approved.

As discussed in previous paragraphs, vocational training is not only about the memorization and accumulation of information but rather about that information being meaningful that allows students to develop skills, skills, values, attitudes to face and "... adapt to a changing, uncertain and complex world, which demands from people in training a process of transformation, necessary to live in today's society characterized by its permanent state of change at a global level..." (Hargreaves, 2003). (Ap. Altuna, et.al., 2021, p. 198)

It is necessary that the authorities of the $\mathrm{UA}$ and the professors consider addressing these issues of importance for the university students since they are topics of transcendence for his future insertion to the labour market. All seem to indicate thatthe educational and labor reforms are notpenetrating enough in the curricular designs; therefore, as Sánchez (2014) comments, it is indispensable "... assume a critical and flexible curricular stance, committed to the network composed of academic knowledge and everyday knowledge that strengthens the sense of solidarity, dignity, responsibility and sensitivity in the human being. (p.71) 


\section{References}

Altuna, J. et. al (2021). Estudio de los espacios profesionales actuales de la Pedagogía: la voz del alumnado y de los profesionales. Teoría de la Educación. Revista Interuniversitaria, 33(2), 195-215. https://doi.org/10.14201/ teri.23714

Centro de Investigación para el Desarrollo, A.C. [CIDAC] (2014). Encuesta de competencias profesionales. ¿Qué buscan -y no encuentran las empresas- en los profesionistas jóvenes?

http://cidac.org/esp/uploads/1/encuesta_compet encias_profesionales_270214.pdf

Constitución Política de los Estados Unidos Mexicanos [CPEUM] (2021). Cámara de Diputados del H. Congreso de la Unión [CDHCU] (DOF 11-03-2021).

http://www.diputados.gob.mx/LeyesBiblio/pdf/ 1_110321.pdf

Horruitiner, P. (2006). La Universidad Cubana: el modelo de formación. La Habana, Cuba: Félix Varela.

Inciarte, A. y Canquiz, L. (2009). Una concepción de formación profesional integral. Revista de Artes y Humanidades UNICA, 10 (2), 38-61. ISSN: 1317-102X. https://www.redalyc.org/articulo.oa?id=170118 863003

Ley Federal del Trabajo [LFD] (2021) Cámara de Diputados del H. Congreso de la Unión [CDHCU] (DOF 23-04-2021).

http://www.diputados.gob.mx/LeyesBiblio/pdf/ 125_230421.pdf

Ley Orgánica de la Administración Pública Federal [LOAPF] (2021) Cámara de Diputados del H. Congreso de la Unión [CDHCU] (DOF 11-01-2021)

http://www.diputados.gob.mx/LeyesBiblio/pdf/ 153_110121.pdf

Llerena, O. (septiembre-diciembre 2015). El proceso de formación profesional desde un punto de vista complejo e histórico-cultural. Actualidades Investigativas en Educación, 15(3).

https://dx.doi.org/10.15517/aie.v15i13.21041
OCDE (2019). Educación superior en México: resultados relevantes para el mercado laboral. Cap. 2 La economía y el mercado laboral https://doi.org/10.1787/a93ed2b7-es

OCDE (2019). Educación superior en México: resultados relevantes para el mercado laboral. Cap. 4 Resultados de los egresados de educación superior en el mercado laboral.

https://doi.org/10.1787/a93ed2b7-es

Sánchez, C. (2014). Los debates en el currículo universitario. Realidades y desafíos. Saber, Universidad de Oriente, Venezuela. Saber, Vol. $26 \mathrm{~N}^{\circ} 1$

http://ve.scielo.org/scielo.php?script=sci_arttext \&pid=S1315-01622014000100011

Reglamento Interior de la Secretaría del Trabajo y Previsión Social [RISTyPS] (2019) Secretaría de Gobernación [SEGOB] (DOF 23-08-2019). https://www.dof.gob.mx/nota_detalle.php?codi go $=5570275 \&$ fecha $=23 / 08 / 2019$ 